Annals of Plant Sciences

\title{
Biosystematics a modern tool for identification of South Indian species of Ipomoea linn.
}

Praveen Dhar T.

Department of Botany, St. Stephen's College, Pathanapuram, Kollam, Kerala, India.

Received: 1/6/2018; Accepted: 1/17/2018

\begin{abstract}
Systematics must be perceived as a science that can hold its own image in the current information era, rather than as an old fashioned stamp collecting exercise and this perception must be presented to both the general and public.To build up a natural system of classification of plants, it is necessary to compare one form with another, such parts like stem, leaf, root, flower, fruits and seeds. These superficial examinations are helpful to a certain extent in identifying and classifying the plants. The phenotype of each and every taxon is unique and this uniqueness itself is a clear identifying feature for a taxon. To a certain extent cytological, palynological, anatomical features seen to go in hand with the external morphological features.
\end{abstract}

Keywords: Biosystematics, Morphology, Epidermal, Palynology, Cytology, Biochemical

\section{Introduction}

Biosystematics is defined as "the study and description of the variation of organisms". The investigation of the causes and consequences of this variation and the manipulation of data obtained helps to produce a system of classification. Biosystematics is an experimental taxonomical study of organisms from the stand point of evolutionary processes which occur within population. It is largely concerned with morphological, anatomical, genetical, cytological, chemical and palynological aspects. Biosystematics may therefore be considered as the taxonomic application of these types of experimental disciplines. Biosystematics although difficult to define precisely, is the consideration of the natural relationships among taxa. It includes the description, naming and classification of organisms together with their evolution and phylogeny. Systematics is mainly based on detailed examination of the floral and vegetative parts lead to a broad based evolutionary understanding of the origin and interrelationship of groups of population. Hence systematic study includes traditional taxonomy with the additional of theoretical and practical aspects of evolution, genetics and speciation.

The word species has a dual connotation in biological science. First, the species is a naturally occurring group of individual organisms that comprise basic unit of evolution. Second the species is a category within a taxonomic hierarchy governed by various rules of nomenclature (Singh, 2004). However, ideal species are rare among the plant kingdom and the vast majority of present day species pose situations contrary to one or more of the above mentioned criteria. So there arises a very significant question for consideration how do

\footnotetext{
${ }^{*}$ Corresponding Author:

Praveen Dhar T.,

Assistant Professor,

Department of Botany, St.Stephens College,

Pathnapuram, Kollam, Kerala, India.

E-mail: dharpraveent@gmail.com
}

determine whether two plants are members of the same species or not. This question has been, continues to be, and intensely debated among systematic and evolutionary biologists. Scientists from various fields of biological science are more interested in species than in any other than taxa (Judd et al., 1999). Eventhough many concepts are available for elucidating a true definition for species, no consensus was finalized in this regard. Part of the reason for the lack of consensus is that the biodiversity is idiosyncratic. Each lineage has a unique history of genetic, morphological and ecological changes of interactions with other species, the physical world of migration and dispersal. Biosystematics is defined as "the study and description of the variation of organisms".

The investigation of the causes and consequences of this variation and the manipulation of data obtained helps to produce a system of classification. Biosystematics is an experimental taxonomical study of organisms from the stand point of evolutionary processes which occur within population. It is largely concerned with morphological, anatomical, genetical, cytological, chemical and palynological aspects. Biosystematics may therefore be considered as the taxonomic application of these types of experimental disciplines. Biosystematics although difficult to define precisely, is the consideration of the natural relationships among taxa. It includes the description, naming and classification of organisms together with their evolution and phylogeny.

\section{Materials and Methods}

In the present research investigation, detailed analysis of various aspects such as morphological, 
epidermal, palynological, cytological and biochemical aspects of South Indian species of Ipomoea were carried out. The detailed morphological studies were carried out in South Indian species of Ipomoea This study includes habit, nature of stem, leaf and areoles features, flower, calyx, corolla, androecium, gynoecium, seed features, nature of fruit and flowering season were taken into consideration. The length and breadth were measured by using centimeter scale, ocular micrometry and weights were measured by using electronic balance (Systronics). Plants were identified with the help of the Flora of the Presidency of Madras (Gamble, 1935) Tamil Nadu, Flora of Carnatic (Mathew, 1983) and Flowering plants of Kerala - a check list (Sasidharan, 2006). In the present study epidermal characters such as type and number of stomata, number of epidermal cells, stomatal frequency, stomatal index, length and breadth of stomata in abaxial and adaxial side, nature, type, length and breadth of leaf, calyx and corolla trichome and leaf venation minor and major, shape, length and breadth of areole were observed by using ocular micrometer. Pollen size is calculated by taking measurements of polar axis and the maximum breadth in the equitorial view of the grain and applying the formula $\mathrm{P} / \mathrm{E} \times 100$. The shape of the pollen grain depends upon three factors (Knox, 1984; Sukhla, et al., 1998) Root tips for somatic chromosome studies were collected from vine cuttings of plants grown in pots containing sand. Seed can also be used for the same purpose. Roots are produced from nodal region. The roots were collected between 12 A.M. and 1 P.M. on bright sunny days. Pre treatment with 0.002M. 8- Hydroxyl quinoline gave satisfactory results. The roots were fixed in 3:1 ethanol: acetic acid medium. Addition of slight ferric acetate on the next day to the fixative was helpful in better staining of the chromosome. Biochemical characters such as quantity of protein, quantity of carbohydrates, and estimation of ergoline alkaloid derivatives were selected for the present study were carried out using standard formula.

\section{Results}

In the present research investigation, detailed analysis of various aspects such as morphological, epidermal, palynological, cytological and biochemical aspects of South Indian species of Ipomoea were carried out. The study of differences between species was properly documented and their significance can be fully grasped by their expression. Major findings emerged from the present study along with its biosystematics consideration is given under appropriate heads as key for identification.

\section{Morphological key}

1. Habit creeper or climber mostly having herbaceous stem.

2. Alternate leaf texture
3. Sepals polysepalous, five in number

4. Petals gamopetalous

5. Stamens five, free, epipetalous

6. Superior ovary with axile placentation

7. Fruit capsule

8. Leaves palmate

9. Leaf apex acute .

10. Leaf margin entire ............... I. cairica

11. Leaf margin serrate ............... coptica

12. Leaf base cuneate ................ digitata

9. Leaf apex acuminate

10. Leaf margin entire ................ horsfalliae

8. Leaves pinnatified

8. Leaves lanceolate to hastate ............ aquatica

8. Leaves broadly ovate and bilobed........... . pes-caprae sub sp. brasiliensis

8. Leaves broadly ovate and lobeless ......

9. Leaf apex acute ......

10. Leaf margin entire ...

11. Leaf base cordate ............. alba

11. Leaf base lobate

12. Flower solitary ................. batatas

12. Flower cymose ................. . hederifolia

9. Leaf apex acuminate

10. Leaf margin entire

11. Leaf base cordate .................... indica

11. Leaf base lobate

12. Flower solitary

13. Corolla rose with white throat ......I. purpurea

13. Corolla yellowish inner pink ......... o. obscura

8. Leaves pinnatified ............. I. quamocilt

1. Habit erect shrub having woody stem........ carnea sub sp. fistulosa

\section{Epidermal key}

1. Eglandular and unbranched trichomes with paracytic stomata, with simple leaf venation

2. Trichomes are present in leaf, calyx, corolla .....I. alba, I. batatas, I. cairica,

I. coptica, I. digitata, I. hederacea,

I. indica, I. obscura, I. purpurea

I. quamoclit

2. Trichomes are absent in leaf and calyx ..... I. hederifolia, I. horsfalliae

I. pes-caprae sub sp. brasiliensis

2. Trichomes present in corolla ........ I. aquatica, I. carnea sub sp. fistulosa, I. staphylina

\section{Palynological key}

1. Pantoporate and spinose type pollen of morphotype and exine ornamentation, spheroidal, pollen shape

2. Pointed type pollen having high fertility.......I. alba, I. aquatica,

I. cairica, I. carnea .sub sp. fistulosa,

I. coptica, I. digitata, I. indica, I. obscura,

I. pes-caprae sub sp. brasiliensis,

I. purpurea I. quamoclit, I. staphylina 
2. Blunt type pollen having moderate fertility .........I. batatas, I. hederacea, I. hederifolia, I. horsfalliae I. quamoclit

\section{Cytological key}

1. Chromosome number $2 \mathrm{n}=30$

2. Chromosome types J, K, L. ...... I. alba, I. cairica, I. carnea sub sp. fistulosa, I. hederacea,

I. hederifolia, I. pes-caprae sub sp. brasiliensis, I. obscura

2. Chromosome types J, K, L, M, R .......... aquatica

2. Chromosome types J, K, L, P, Q......... indica, I. purpurea

2. Chromosome types J, K, M I. coptica

2. Chromosome types J, K, E........... digitata

2. Chromosome types K,L,P ........ quamoclit

1. Chromosome number $2 \mathrm{n}=28$

2. Chromosome types J, K, L....... I. horsfalliae

1. Chromosome number $2 \mathrm{n}=32$

2. Chromosome types J, K, L. ....... staphylina

1. Chromosome number $2 \mathrm{n}=90$

2. Chromosome types J, K, L, P, Q....I. batatas

\section{Biochemical key}

1. Ergoline derivative D- Lysergic acid diethyl amide is absent......I. coptica

$$
\text { I. horsfalliae }
$$

1. Ergoline derivative elymoclavine is absent .................. I. digitata,

I. obscura,

I. quamoclit

\section{Conclusions}

Through the present investigation, most of the species of Ipomoea in South India have been catalogued and classified. The problems related to their identification was solved to a great extent by adopting keys pertaining to morphological, epidermal, palynological, cytological and biochemical aspects. Even though there was found variation in the cytological characters among some species of Ipomoea, a close resemblance has been observed in the morphological, palynological, epidermal and biochemical features. The variation in chromosome numbers of different species of Ipomoea has a great evolutionary significance. It is also noted that the polyploidy has a great influences on evolutionary trends in each and every species that will affect all other characters. The present research investigation also support the view of placing the genera Ipomoea as a separate genera under the family Convolvulaceae. The investigator would feel gratified if the findings of the study would lead to the better understanding of the biosystematics of South Indian species of Ipomoea.

\section{References}

1. Choisy, J.D. "Convolvulaceae In Prodromus systematis naturalais regni vegetabilis" $A$. $P$. DeCandolle (ed), Paris France, V. 9: (1845) 323-462. Print

2. Clay, K. and Schardl, C. "Evolutionary origins and ecological consequences of endophyte symbiosis with grasses". Am. Na.t (Suppl) 160 (2002) 99-127. Print

3. Gamble, J.S. Flora of Presidency of Madras. Bot. Surv. India, Calcutta. Vol.II (1921) Print

4. Gamble, J.S. Flora of Presidency of Madras. Bot. Surv. India, Calcutta Vol. II (1923).Print

5. Gamble, J.S. Flora of the Presidency of Madras. Bot. Surv.India, Calcutta. Part I. (1935) Print

6. Judd, W.S., Campbell, C.S., Kellog, E.A. and Stevaens, P.E. Plant systematics Sinauer Associates, Inc. Massachusettes. (1999)Print

7. Mathew, K.M Flora of the Tamil Nadu Carnatic. Diocesan Press, Madras. Vol.I (1983) Print

8. Sasidharan, N. "Flowering Plants of Kerala - A check list" Kerala Forest Reseach Institute, Peechi. (2006) Print

9. Singh, G. "Plant systematics" Oxford and IBH Publishing Co. New Delhi (2004) Print

10. Singh, V.I., D.K. Jain and Meena Sharma. "Leaf architecture in Berberidaceae and its bearing on the circumscription of the family". J. Ind. Bot. Soc. 57 (1978) 272-281. Print

\section{Cite this article as:}

Praveen Dhar T. Biosystematics a modern tool for identification of South Indian species of Ipomoea linn. Annals of Plant Sciences 7.2 (2018) pp. 2013-2015.

do http://dx.doi.org/10.21746/aps.2018.7.2.5 